\title{
UKRAINIAN SONG FOLKLORE IN THE CONTEXT OF CURRENT TRENDS IN THE DEVELOPMENT OF MUSICAL PEDAGOGY ${ }^{1}$
}

\author{
Sun Pengfei \\ $\mathrm{PhD}$, Senior Lecturer, School of Art, Yangtze University, China \\ e-mail: alex1973@i.ua, orcid.org/0000-0003-0599-1504
}

\begin{abstract}
Summary
The article discusses the pedagogical potential of Ukrainian song folklore in the context of current trends in modern musical pedagogy. Song folklore is considered as the main identifier of the national musical tradition and reflects the non-musical factors of its specificity. These factors ensure the success of the study of Ukrainian music by representatives of other cultures and reflect the main ideas of the cross-cultural direction of music education, in the mainstream of which the interactions of the modern pedagogical experience of Ukraine and China are formed. Ukrainian song folklore as a semiotic system is considered as didactic material, which is aimed at the formation of the semiotic competence of a music teacher. The proposed method allows the student to form a conscious perception of a folk song as a "genocode" of national culture, which is expressed in the symbolic form of the musical language. Song folklore is also promising for the integrational direction of artistic pedagogy. It is based on the principle of using interdisciplinary connections of various types of arts in the educational process.
\end{abstract}

Keywords: cross-cultural didactics, professional competence, semiotic competence, Ukrainian song.

DOI https://doi.org/10.23856/3929

\section{Introduction}

In the context of modern culture, which in the era of globalization develops under the sign of integration processes, the education system must be sensitive to the needs of society and master new principles of educating professionally competent specialists. Music pedagogy in this context is considered as that link in the education system, which is responsible for the preservation of the spiritual values of human culture and their relaying for each new generation. This function of art education ensures the continuity of traditions and the possibility of national and cultural identification of the art phenomenon, the need for which is so often emphasized by modern sociologists and art historians. Musical folklore, which is one of the main identifiers of national culture, today more than ever is an actual object for the system of musical education, since it has a powerful pedagogical potential. This relevance is greatly enhanced if we are talking about a cross-cultural vector of development of modern musical pedagogy, in the mainstream of which a system of interconnections of the modern pedagogical experience of Ukraine and China is being formed. The scientific novelty of this research is due to the theoretical substantiation of the pedagogical potential of Ukrainian song folklore in the process of forming the professional competence of future music teachers (in the context of the competence and integration directions of pedagogy). The purpose of the study is to determine those systemic and functional indicators of Ukrainian song folklore, which constitute the method of forming

This study was supported by the Education Science Planning Project Program of the Hubei Provincial Department of Education, China (2019GB025). 
a correct understanding of the national musical tradition in the process of special education of future music teachers. The research tasks are conditioned by the set goal: to designate the pedagogical possibilities of studying Ukrainian song folklore in the context of current trends in modern pedagogy; on the basis of the semiotic properties of the Ukrainian song folklore, consider it in the context of the methodological principles of the formation of the semiotic competence of a musical teacher; to discuss the pedagogical possibilities of song folklore in the context of the integration direction of modern musical pedagogy. The research methodology consisted of a system-functional method (in defining song folklore as a form of spiritual culture and an object of pedagogical practice), a comparative method (in substantiating the methodological resources of Ukrainian folklore in the context of current trends in modern musical pedagogy), as well as a method of pedagogical observation.

\section{Musical folklore in the context of cross-cultural didactics}

In the era of globalization, significant transformations of traditional principles are taking place in the education system, which are associated with new human conditions in the modern world, a new type of personal identity and new types of social and cultural communication. The need of conformity of the methods of vocational education with the actual needs of our time generates new directions of pedagogy, which attempt to create the process of education of future specialists in a variety of professional fields that is adequate to the modern image of the world. One of these areas is cross-cultural didactics, which today is a special area of pedagogy. This direction can be considered as a priority for the cultural orientation of modern China on the development and accumulation of European and American cultural experience and it is an active intercultural dialogue. Musical pedagogy in this sense is directly related to the cross-cultural trend of modern education, since it is focused on educating a new generation of specialists - teachers, performers, historians and theorists, whose professional activities are related to globalized consciousness. The idea of "intersection of cultures", which lies in a basement of cross-cultural pedagogy reflects the realities of modern civilization, which exists according to the laws of communicative interaction of cultural traditions. I. Bekh, an outstanding representative of modern pedagogy, identifies two main functions of cross-cultural dialogue: adopted-logical (adopting a certain way of thinking - cognitive, technological, artistic, spiritual and moral) and researching (orientation towards finding innovative solutions to urgent problems, here a developed dialogical dispute arises, a clash of ideas, approaches, methods of action) (Bekh, 2013: 81).

According to experts in the field of cross-cultural didactics, the most important goal is to overcome the problems related with the traditions of the education system, which was focused on the formation of monocultural consciousness as a factor of national identity. According to A. Dzhurinsky, the principle of extrapolation of the socio-cultural values of the dominant culture into the sphere of professional education, is fundamental for this system and its pedagogical methods and techniques (Dzhurinsky, 2015). Nowadays, this principle lends itself to rethinking and adaptation to new conditions for the development of personality and the formation of professionalism in an open world space. And in this context, the active dialogue between China and Ukraine, which has long practical realisation in the field of musical pedagogy, proves the success of mastering an "alien" musical tradition through intercultural humanitarian discourse. For representatives of Chinese musical culture, the result of the going beyond its national borders and the installation on the integration principle of educating professional musicians and teachers has expressed in a whole layer of dissertation research by Chinese specialists in the field of musicology and music pedagogy, successfully defended in Ukraine over the past decades. 
The study of "alien" musical culture and the formation of an adequate professional understanding of it through musical folklore is quite natural: folk art has always been understood as the most representative phenomenon of national culture, as a concentrate of ideas about the world and about a person in the world, expressed in literary, poetic and musical form. And song folklore is even more indicative in this regard - the song is often called the "heart and soul" of the people, that genre-style form that can be considered as an "intonational image of the world" (Chekan, 2010).

The universalism of the folklore tradition provides great opportunities for a comprehensive study of musical culture, which incorporates various aspects of the existence of song folklore - its verbal and poetic component, musical language, types of performing practice, as well as conditions of functioning. L. Sbitneva states the actualization of musical folklore for modern pedagogy: "Folk musical creativity is increasingly being introduced into the school educational process as a unity of musical performing, author's, listening, folk pedagogical, ritual and festive activities" (Sbitneva, 2016: 197). The ancient views and ideas of mankind about the world have enough character of universality for all times. Folk spiritual culture covers the whole system of views of this ethnos on nature and man. It is reflected in calendar and family rituals, games and entertainment, songs, fairy tales and much more. Therefore, musical folklore is a syncretic phenomenon: it is a complex of verbal-poetic, play (dramatic), musical and choreographic types of folk art. This understanding of folk musical creativity naturally fits into the holistic context of folk culture. Ukrainian song folklore personifies in its numerous samples the universal knowledge and ideas about the world and man immanent in its national culture. This determines its status as the spiritual heritage of Ukrainian culture, which, through specific means of expression (musical and poetic), fixes its ontological meanings and opens up the prospect of enriching the individual professional and human experience of a student and a teacher.

Considering Ukrainian song folklore as an object of musical pedagogy, it is necessary to take into account the main factors of the oral tradition, the product of which is folk music. These factors are as follows: 1) continuous connection of the present creative experience with the past; 2) variability arising from the creative impulses of an individual or group; 3) the selection of means of expression, which is carried out by the collective creative consciousness and determines the specific forms in which the song is passed on to the next generations (Zemtsovsky, 1976: 887). Among the numerous definitions of folklore, the concept of E. Alekseev, based on the principle of "bilingualism of culture", stands out: the researcher notes the incorrectness of the opposition of the concepts "folk" and "professional", therefore he operates with the opposition "verbal - written". According to the scientist, the development of musical culture is "a parallel movement of two interacting, but finally not mixing streams, a kind of "confrontation", or better - a dialogue of two significantly different types of musical thinking" (Alekseev, 1988: 77). The collectivity of musical consciousness in this case is due to the existence of a single system of values and rules for the national culture. As you know, most of the folklore song material is ritual genres that initially existed only in ensemble singing and the collective nature of the content of such songs reflects the thinking, worldview and psychology of the people. In folklore works, the person does not separate himself from the collective and, moreover, does not oppose himself to it.

The indicated signs of musical folklore allow representatives of Ukrainian musical pedagogy to assert that "The pedagogical expedience of using songs of Ukrainian folklore in the upbringing of schoolchildren" is justified by their artistic perfection, accessibility of images, clarity of melody. The pedagogical potential of song folklore lies primarily in intonational melodiousness, a certain lapidary melody and rhythmic structures, direct emotionality ... in the depiction of reality, that is the projection of the history of the life of the people, their thoughts, feelings ... Thanks to this, there is a moral and ethical formation, a connection 
between generations (Kablova, 2017: 130). If we consider Ukrainian song folklore as a "tool" for studying Ukrainian musical culture and forming special knowledge of a musician-teacher (especially if he is a bearer of another national tradition), then it organically fits into the concept of multicultural musical education by D. Elliott, who identified six degrees acquaintance with world musical cultures (Elliott, 1989). The highest sixth degree ("dynamic multiculturalism") is based on the principle of studying the music of any culture, taking into account the general socio-cultural context in which this music functions. According to the American music teacher, this principle provides the opportunity for music education as a humanistic upbringing and gives the individual a chance to appropriate the values of world culture and the opportunity to know himself deeper through understanding others (Elliott, 1989).

\section{Folklore and semiotic competence of a music teacher}

Ukrainian song folklore in its genre diversity has semantic properties that ensure its communicative function and the continuity of tradition. Being in essence a sign-symbolic system, the song genre through musical and artistic images broadcasts information about the system of spiritual values of national culture and a particular picture of the world. The semiotic aspect of musical folklore, which is directly related to the verbal textual basis of the song and its musical and intonational embodiment, is highly promising for the current trends in modern musical pedagogy. This is due to the fact that the study of folk art opens up wide opportunities for the formation of the semiotic competence of a future music teacher, which is necessary for him to be successful in his professional activity. It should be noted that one of the most developed areas of modern art pedagogy (professional competent) does not specifically highlight the problem of the semiotic competence of a future specialist. The competence direction, represented in Ukrainian pedagogy by the theoretical concepts of L. Masol, N. Miropolskaya, O. Onishchenko, A. Khutorsky and others, defines as its main setting the formation of a complex of ideas, skills and abilities that form the artistic competence of a student. It is about educating a "literate consumer" of artistic culture, capable for "independent artistic activity" (Solomakha, 2009: 7). In modern art pedagogy, varieties of competencies are divided for basic (leading, key, universal) and special (specific and subject-professional) (Masol, 2006). However, in the classification of these competencies, we do not find any semiotic competence, which is directly related to the process of mastering and studying musical art (Masol, 2006: 44-45). It is obvious to us that these competencies are implied in some of the points of this classification, although they are not indicated by special concepts. So, for example, a variety of personal competencies are special ones, among which there are the following: artistic thesaurus, mental aesthetic experience, artistic imaginative thinking, and artistic and creative abilities (Masol, 2006: 45). All these qualities of a person are formed in the cultural context of her life and her environment - the semiosphere. Communication of a person with the genre diversity of Ukrainian song folklore in the learning process will in any case be corrected by its individual semiotic experience, and the specificity of professional competence that is formed in the educating process will depend on it. Mental aesthetic experience is also formed in this context, and creative abilities which responsible for imaginative thinking are directly related to the symbolic nature of art. Also, in this pedagogical direction, a number of functional competencies are distinguished, among which two are especially relevant for us: subject knowledge and skills (musical, visual) and interdisciplinary - sectoral (artistic and aesthetic) and intersectoral (artistic and humanitarian) (Masol, 2006: 45). The semiotic aspect of these competencies is obvious, since, as already mentioned, they are all formed in the semantic space of musical culture. The point is that each 
of the above competencies - special and functional - are interconnected with the semiotic side of musical pedagogy, for which folk song is an essential factor in the upbringing of a "literate consumer" of musical art and an adequate relay of its national and cultural meaning. Ukrainian song folklore contains many symbolic images and archetypes of national culture. The song in the everyday life of the Ukrainian people began to establish itself from ancient times: first as a component of pagan rituals, then as part of its history. Meanwhile, the character of song folklore changed: the ceremony disappeared, but the verbal text continued to exist independently of it. Under the new conditions, the song began to live a different life - folklore, performed without connection with the rite and practical purpose, became an artistic phenomenon.

The song as a folklore genre traditionally played a double role: it acted both as an independent aesthetic phenomenon and as a component of syncretic ritual action. Song folklore has social foundations and a specific aesthetics that reflects its applied functions. Ukrainian song folklore reproduces national and cultural ideas about time in a different dimension. So, in the figurative-symbolic system of Ukrainian songs, a specific understanding of time is reflected by lexemes of a non-temporal nature (such as a horse, a rooster, an apple, a candle), lexemes of astral-temporal semantics (day, night, sun, twilight, etc.), spatially temporal lexemes (tree, sea, field, meadow). This is due to the connection of song folklore with the worldview and worldview of a person, his picture of the world. In ritual texts, which are a verbal component of song folklore, images-symbols (bread, water, fire, house, sun, moon, circle) are close to signs with a relatively definite meaning (circle is the sun, goat is a symbol of fertility and harvest, young moon - the man, the sun - the woman, etc.). The system of figurative symbolism of ritual song folklore mainly reveals the cyclical perception of time, it has rather wide, but traditional meanings. This is due to the fact that their formation took place at the earliest stages of Slavic culture and is associated with mythological consciousness. So, youth is symbolized by spring as the time of awakening of nature, water is the unity of people. The archetypal meaning of viburnum has become a symbol of femininity, beauty, youth, and also a symbol of Ukraine. The figurative parallelism of the age of man and nature is widely represented both in family and household songs and in lyric songs (grass - girl, wheat - woman). We are primarily interested in the figure of the teacher, who in his work encounters the "difficulties of translating" the musical content and meaning into verbal-conceptual structures in order to tell the students "what the listened music means, what it is about". The expediency of the teacher's conscious attitude to his main "instrument" of communication with students, namely to verbal speech, is also obvious. The teacher must consciously and skillfully choose verbal means and other signs that are advisable to use in each specific educational situation. In one case, it will be a comparison with some object or phenomenon of reality, in the other - an emphasis on some qualitative feature of musical content, in the third - the use of images-concepts of a more objective order to explain the spiritual or philosophical content of a musical work, etc. One way or another, a music teacher needs a conscious possession of knowledge about the signs that musical art uses, and which he himself uses in the process of explaining musical works.

\section{Folklore in the integrational direction of musical pedagogy}

Song folklore is also promising for the integrational direction of artistic pedagogy. It is based on the principle of using interdisciplinary connections of various types of arts in the educational process and is widely represented in Ukraine (B. Yusov, P. Blonsky, O. Rudnitskaya, O. Shcholokova, L. Masol, T. Tanko, O. Otich and others). In this direction, the teacher's ability to correctly interpret and explain the expressive means of various arts is important, 
and, accordingly, teach students to have their own interpretation. So, one of the principles of B. Yusov's "polyartic" education is the development of artistic perception among students (knowledge in the field of art, responsiveness to its language, aesthetic judgments about art), as well as the "skills of perceiving an artistic image" in an artwork (Yusov, 1984).

In this case, we are talking about the so-called "interdisciplinary connections" - a pedagogical idea, which today is embodied in the integration approach. Getting acquainted with a concrete example of Ukrainian song folklore, the student has the opportunity to get an idea of the wide information field of Ukrainian culture. This may include analogies with other types of art (painting, sculpture, literature), as well as philosophical and religious ideas of national culture, historical events and even the history of costume. So, for example, the study of Ukrainian song folklore of the late period (dumys, historical, Cossack, Chumak songs) has the immediate prospect of getting to know the events of national history and their reflection in literature and fine arts. This spectrum of perception of musical material creates a "multidimensional" idea of the Ukrainian song and makes it possible to develop the skill of recognizing the special attributes of national culture. If we talk about archaic Ukrainian song folklore (calendar and ritual songs), they open up wide opportunities for a comprehensive consideration of Slavic mythology, the peculiarities of the religious consciousness of the ancient Slavs, and the way of their daily life. Similar didactic opportunities are associated with social and family songs. The first group reflects the social life of the Ukrainian people (social problems associated with historical, economic and political processes). These songs reflect the life of not a one person, but a certain segment of the population, a social group (Cossacks, recruits, etc.). And family songs reflected the individual life of a person (family relationships, personal dramas and conflicts, etc.) (Lanovik, 2006: 322). This thematic area had a great influence on the development of the musical language of song folklore: specific types of emotions were formed in it, which found their artistic embodiment in a specific type of musical expression. In a lyric song, the content is revealed primarily by the melody, in contrast to ritual genres, where declamation plays the leading role. This determines the special flexibility of the melody of Ukrainian lyric songs, a special tonal colour, conveying the change of moods and emotions. For Ukrainian lyric songs, the key ratio is typical of the major-minor type, less often the keys of the same name are compared. Melodic expressiveness is often achieved through a sharping of the IV step in minor key. As you can see, the musical expressiveness of Ukrainian folk song can be considered in the context of non-musical factors: such an intersubjective discourse has wide pedagogical possibilities. And this approach is especially relevant for the study of Ukrainian music by foreign students who come across in the learning process with a "alien" musical tradition and feel difficulties in its perception.

\section{Conclusions}

Summarizing our reasoning, we note that the appeal to the topic of this study reflects the urgent needs of modern music pedagogy related to the problem of intercultural interactions. We regard Ukrainian folk songs as an important identifier of the national musical tradition; it has the ability to directly influence the process of forming the professional qualities of a musician. Therefore, the study of Ukrainian song folklore proposed in the article in a national-cultural context (integration method) provides the semiotic competence of a music teacher. The main indicators of this competence include: the amount of ideas about the information-semiotic field of Ukrainian culture, personal artistic experience in this field, orientation in the variety of manifestations of Ukrainian musical culture, the ability to independently and constructively select 
signs and symbols of Ukrainian folk art in the pedagogical process. The proposed method allows the student to form a conscious perception of a folk song as a "genocode" of various senses of national culture, which are expressed in the symbolic form of the musical language.

\section{References}

Alekseev, E. E. (1988). Folklor v kontekste sovremennoj kultury [Folklore in the context of modern culture]. Moscow: Sovetskij kompozitor. [in Russian]

Bech, I. D. (2013). Dialoh kultur u psykholoho-pedahohichnomu osmyslenni [Dialogue of cultures in psychological and pedagogical understanding]. Aktualni pytannia mystetskoi osvity ta vykhovannia. No. 1 (2), 79-84. Khmelnitsky: Khmelnytska humanitarno-pedahohichna akademiia. [in Ukrainian]

Dzhurinskiy, A. N. (2015). Teoriya i metodologiya istorii pedagogiki i sravnitelnoj pedagogiki. Aktualnye problem [Theory and methodology of the history of pedagogy and comparative pedagogy. Actual problems]. Moscow: Prometej. [in Russian]

Zemtsovsky, I. I. (1976). Narodnaya muzyka [Folk music]. Musical encyclopedia. In 6 vol. Vol. 3. Moscow: Sovetskaya enciklopediya. [in Russian]

Kablova, T. B., Pavlova, S. O. (2017). Ukrainskyi pisennyi folklor u muzychnomu vykhovanni shkoliariv [Ukrainian song folklore in musical education of schoolchildren]. Muzychne mystetstvo $v$ osvitolohichnomu dyskursi. No. 2, 128-132. Kiev: Kyivskyi universytet im. B. Hrinchenka [in Ukrainian]

Lanovik, M. B., Lanovik, Z. B. (2006). Ukrainska usna narodna tvorchyst [Ukrainian unwritten folk art]. Kiev: Znannya-Pres. [in Ukrainian]

Masol, L. M. (2006). Metodyka navchannia mystetstva u pochatkovii shkoli [Methods of creating a masterpiece at the Elementary School]: navchalnyi posibnyk. Kharkov: Vesta: Ranok. [in Ukrainian]

Oleksyuk, O. M. (2014). Muzychno-pedahohichne doslidzhennia v konteksti novykh suspilnoistorychnykh realii [Musical and pedagogical research in the context of new social and historical realities]. Naukovi zapysky Kirovohradskoho derzhavnoho pedahohichnoho universytetu im. V. Vynnychenka. Seriia: Pedahohichni nauky. Issue 133 (1), 33-41. Kirovograd: RVV KDPU im. V. Vynnychenka. [in Ukrainian]

Sbitneva, L. M. (2016). Tendentsii rozvytku muzychnoi osvity v Ukraini na pochatku XXI stolittya [Trends in the development of music education in Ukraine at the beginning of the XXI century]. Dukhovnist osobystosti: metodolohiia, teoriia i praktyka. No. 5 (74). Northern Donetsk: Vydavnytstvo SNU im. V. Dalia, 192-200. [in Ukrainian]

Solomakha, S. O. (2009). Metodolohichni pidkhody do rozvytku khudozhno-estetychnoho svitohliadu vchyteliv mystetskykh dystsyplin v systemi pisliadyplomnoi pedahohichnoi osvity [Methodological approaches to the development of artistic and aesthetic worldview of teachers of art disciplines in the system of postgraduate pedagogical education]. URL: http://lib.iitta. gov.ua/3546/ [in Ukrainian]

Chekan, Y. I. (2010). Intonatsiinyi obraz svitu yak katehoriia istorychnoho muzykoznavstva [Intonation image of the world as the category of historical musicology]. Thesis for a doctoral degree of arts in the speciality 17.00.03 - Music Art. Ukrainian National P. I. Tchaikovsky Academy of Music. Kiev. [in Ukrainian]

Yusov, B. P. (1984). Problema hudozhestvennogo vospitaniya i razvitiya shkolnikov [The problem of artistic education and development of schoolchildren]: Thesis for a doctoral degree of Pedagogical Sciences in the speciality 13.00.01 - General pedagogy, history of pedagogy and education. Moscow. [in Russian]

Elliott, D. J. (1989). Key Concepts in Multicultural Music Education. International Journal of Music Education. No.13, 11-18. [in English] 